\title{
Effect of processing technology on the physicochemical properties of non-centrifugal cane sugar (NCS)
}

\author{
Efecto de la tecnología en los cambios de composición en el proceso de fabricación de panela
}

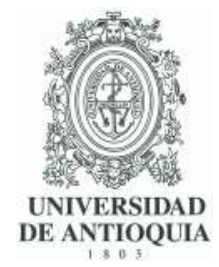

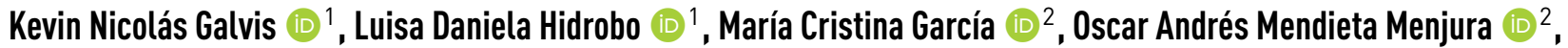 Martha Patricia Tarazona-Díaz
${ }^{1}$ Grupo de Investigación en Ingeniería de Procesos y Sistemas Industriales, Departamento de Ingeniería, Facultad de Ciencias Naturales e Ingeniería, Universidad Jorge Tadeo Lozano. Carrera 4 \# 22-61. A.A. 34185. Bogotá, D.C., Colombia.
${ }^{2}$ Grupo de Investigación en Tecnologías de Mecanización Agrícola y Procesos Industriales, AGROSAVIA Corporación Colombiana de Investigación Agropecuaria. Km 14 vía Mosquera. A. A. 250047. Bogotá, D.C., Colombia.

\section{CITE THIS ARTICLE AS:}

K. N. Galvis, L. D. Hidrobo, M.

C. García, O. A. Mendieta and

M. P. Tarazona. "Effect of

processing technology

(traditional and ward furnace)

on the physicochemical

properties of non-centrifugal

cane sugar (NCS)", Revista

Facultad de Ingeniería

Universidad de Antioquia, no.

95, pp. 64-72, Apr-Jun 2020.

[Online]. Available: https:

//www.doi.org/10.17533/

udea.redin. 20190839

\section{ARTICLE INFO:}

Received: August 22, 2018 Accepted: August 26, 2019

Available online: August 26, 2019

\section{KEYWORDS:}

Non-centrifugal cane sugar; physical and chemical properties; ward furnace; evaporation

Panela; propiedades fisicoquímicas; horno de sala; evaporación
ABSTRACT: Non-centrifugal cane sugar (NCS) is a natural sweetener with beneficial health properties. This is traditionally produced in an oven which has had technological variations. Therefore, the present study focuses on determining the effect that NCS processing technology has on its physicochemical properties. In this study, two contrasting technologies were selected: the first one corresponds to the traditional furnace, characterized by a flat combustion chamber and hemispherical pan. The second one corresponds to the furnace with a ward type combustion chamber and modified pan. The variety of sugarcane selected was RD 75-11. The physical and chemical parameters evaluated were hydrogen potential $(\mathrm{pH})$, total acidity (TA), solid soluble content soluble (SSC), ash, minerals, reducing sugars, color, moisture content and heat capacity. The technology with ward- type combustion chamber and modified pan managed to concentrate the ${ }^{\circ}$ Brix of syrup to NCS in a $36.03 \%$ unlike the traditional furnace $(32.59 \%)$. The two technologies used allowed obtaining NCS with an average caloric value of $14684.9 \mathrm{~J} \mathrm{~g}^{-1}$ and soluble solid content of $90.1^{\circ} \mathrm{Brix}$. It was found that the NCS is a source of minerals such as potassium $\left(3.55 \mathrm{~g} \mathrm{~kg}^{-1}\right)$, calcium $\left(2.25 \mathrm{~g} \mathrm{~kg}^{-1}\right)$ and phosphorus $\left(0.3 \mathrm{~g} \mathrm{~kg}^{-1}\right)$.

RESUMEN: La panela es un edulcorante natural con propiedades beneficiosas para la salud. Ésta se produce tradicionalmente en un horno, el cual ha tenido variaciones tecnológicas. Por tanto, el presente estudio se enfoca en determinar el efecto que tiene la tecnología de procesamiento de la panela sobre sus propiedades fisicoquímicas. En este estudio, se seleccionaron dos tecnologías contrastantes: la primera corresponde al horno tradicional, caracterizado por una cámara de combustión plana y pailas hemisféricas. El segundo corresponde a un horno con cámara de combustión tipo ward y pailas modificadas. La variedad de caña estudiada fue RD 75-11. Los parámetros físicos y químicos evaluados fueron potencial de hidrógeno (pH), acidez total (AT), contenido de sólidos solubles (CSS), ceniza, minerales, azúcares reductores, color, contenido de humedad y capacidad calorífica. La tecnología con cámara de combustión tipo ward y pailas modificadas lograron concentrar los ${ }^{\circ}$ Brix de miel a panela en un $36.03 \%$ a diferencia del quemador tradicional (32.59\%). Las dos tecnologías utilizadas permitieron obtener panela con un valor calórico en promedio de $14684.9 \mathrm{~J} \mathrm{~g}^{-1}$ y una concentración de sólidos solubles de $90.1^{\circ}$ Brix. Se comprobó que la panela es un alimento rico en minerales como potasio $\left(3.55 \mathrm{~g} \mathrm{~kg}^{-1}\right)$, calcio $\left(2.25 \mathrm{~g} \mathrm{~kg}^{-1}\right)$ y fósforo $\left(0.3 \mathrm{~g} \mathrm{~kg}^{-1}\right)$.

\section{Introduction}

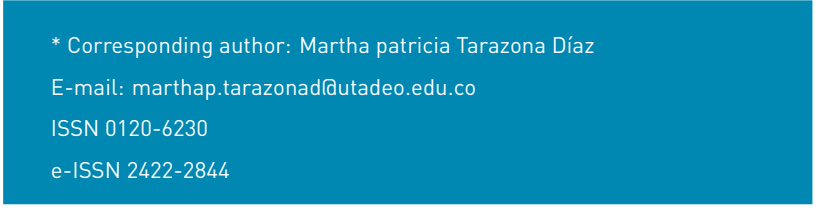

Non-centrifugal cane sugar (NCS) is a solid product sold in different forms (tablets or bricks, cones, round); it is the result of the evaporation of sugarcane juice 
(Saccharum Oficinarum), without centrifuging, maintaining its constituent elements as sucrose, glucose and minerals [1].

Its name varies depending on the country; Panela (Colombia, Guatemala, Panama, Ecuador and Venezuela), rapadura (Brazil), chancaca (Peru and Bolivia), piloncillo (Mexico), raw sugar, brown sugar, muscovado (USA), jaggery (Africa and Asia), gur (Asia), moscavado and panutsa (Philippines), kokuto and black sugar (Japan) [2]. Sugarcane is the third most important commodity in the world, with a larger production in the Americas (54.1\%), followed by Asia (39.1\%), Oceania (1.7\%) and Africa (5.1\%). Colombia ranks seventh among the countries with the highest production in the world with 34.535.753 MT (FAO, 2016). It is preceded by countries such as Brazil, India, China, Thailand, Pakistan and Mexico [3]. NCS is consumed for two main reasons: it is used as food for feeding the population due to its nutritional quality, and second, it is as a sweetening ingredient for other foods [4]. It has a high sucrose content (765.5-894.8 $\left.\mathrm{g} \mathrm{kg}^{-1}\right)$, followed by reducing sugars (36.9-105 $\mathrm{g} \mathrm{kg}^{-1}$ ), water (15-158 $\mathrm{g} \mathrm{kg}^{-1}$ ), minerals (3-36 g kg-1), protein (3.7-17 $\mathrm{g} \mathrm{kg}^{-1}$ ) and fats (0-1 $\mathrm{g} \mathrm{kg}^{-1}$ ) [5]. Its consumption has a positive effect on the immune system. It also has anti-toxicity and cytoprotective effects, anticariogenic effects, diabetes and hypertension effects; positive health effects can be due to the presence of minerals and antioxidants [2].

The process to produce NCS begins with the milling of the sugarcane to obtain juice, as the main product, and bagasse as a by-product, which constitutes the fuel for the concentration of the juices. Afterwards, the juice goes through a pre-cleaning system, where solid impurities are removed. Then, it goes to the clarification stage where the suspended solids are removed. After that, the juice goes to the concentration zone in open heat exchangers or "pan" where it is concentrated to $70^{\circ}$ Brix. This concentration is obtained through the energy coming from the bagasse obtained in the grinding.

The NCS production requires a higher concentration of soluble solids between 92 to 95 . ${ }^{\circ}$ Brix [6]. Finally, NCS goes through a process of beating, molding, cooling, demolding, packaging and commercialization.

The technological development in NCS making process has focused on ensuring the self-sufficiency of the system, by increasing its energy efficiency. In order to achieve this, AGROSAVIA-CIMPA IColombian Corporation for Agricultural Research - Research Center for the Improvement of NCS Agroindustryl has worked both in improving the efficiency of the combustion system and heat transfer from the combustion gases towards heat exchangers or pan. In the first case, the combustion chambers have been modified to take advantage of the calorific value of bagasse. Although they have different models, the most efficient to date consists of the "Ward Cimpa" furnace, which allows the pre-drying and complete combustion of the bagasse, by having a second air inlet, which allows reaching a greater temperature of combustion gases. As for the increase of the efficiency of the heat transfer process, different types of pans (finned, fire-tube, hemi-sphericall have been designed, looking for greater contact area and increased heat transfer coefficients.

In this study, the objective was to evaluate the effect of the two technologies Itraditional furnace with flat combustion chamber and hemi-spherical pan, and improved furnace with ward combustion chamber and modified pan) on the physicochemical parameters throughout the agroindustrial manufacturing process.

\section{Materials and methods}

\subsection{Plant material}

The plant material (cane variety RD 75-11) was cultivated in the fields located in the Department of Boyacá, in central Colombia, in the eastern Andes. Sugarcane was harvested at its maturity stage suitable to produce NCS (16 months).

\subsection{Processing technologies}

The compositional changes of the sugarcane juice were analyzed in two NCS production technologies: traditional furnace with flat combustion chamber and hemi-spherical open pan (T1), and improved furnace with ward combustion chamber and modified open pan (T2). Both processing technologies were operated with a mixed flow.

The traditional furnace used for the study had five hemi-spherical open pans in stainless steel. The floors and walls that supported the open pan, as well as the chimney were constructed in brick and semi-refractory mortar. The furnace had a flat combustion chamber, in which the thermal energy needed to carry out the production process of NCS was generated. The juice was manually transferred from one pan to another.

The improved furnace had modified pan with greater area of heat transfer, in which fins were used. In total, seven pans were used in the improved furnace, three open pans with fins and four hemi-spherical open pans, made of stainless steel. The furnace had a ward combustion chamber, in which the bagasse was burned. In this type of furnace, the juice is transferred by gravity through a pipe. 


\subsection{Sample preparation and processing}

The harvested sugarcane was stored for $12 \mathrm{~h}$, and then it was fed to the mill to extract the juice. The bagasse or residue of the cane was taken to the bagasse stocking area where it was subjected to a natural drying process. The juice entered the making process where it was cleaned, concentrated, beaten and molded to obtain the NCS.

\subsection{Sampling}

Sampling was started from the milling of the cane. Each batch lasted approximately 3 hours. Three lots were sampled for each NCS processing plant. Sampling was performed in 9 points: $\mathrm{X} 1=\operatorname{mill}\left(22^{\circ} \mathrm{C}\right), \mathrm{X} 2=$ pre-cleaner $1\left(22^{\circ} \mathrm{C}\right), \mathrm{X} 3=$ pre-cleaner $2\left(22^{\circ} \mathrm{C}\right), \mathrm{X} 4=$ clarifier $1\left(95^{\circ} \mathrm{C}\right), \times 5=$ clarifier $2\left(96-97^{\circ} \mathrm{C}\right), \mathrm{X6}=$ syrup $\left(105^{\circ} \mathrm{C}\right), \mathrm{X} 7=\mathrm{NCS}$ point $\left(120^{\circ} \mathrm{C}\right), \mathrm{X} 8=$ after whipping $\left(100^{\circ} \mathrm{C}\right)$ and $\mathrm{X} 9=\mathrm{NCS}\left(22^{\circ} \mathrm{C}\right)$. At each sampling point and in each lot, 3 samples of 1 Liter were taken every hour, except at the sampling points; $X 7, X 8(300 \mathrm{~mL})$ and X9 (250 g of NCS). All samples were frozen at $-30{ }^{\circ} \mathrm{C}$ until analyzed. Samples $X 6, X 7, X 8$ were taken directly into glass containers previously sterilized $\left(121^{\circ} \mathrm{C}\right.$ for $\left.15 \mathrm{~min}\right)$, and sample $\mathrm{X} 9$ in sterile bags. All physicochemical analyzes referenced below were performed in triplicate.

\subsection{Analysis of physical and chemical properties}

PH, soluble solid content, total acidity and moisture content

The analytical parameters hydrogen potential $(\mathrm{pH})$ (AOAC 981.12) (S20 SevenEasy pH, Mettler Toledo, Bogotá, Colombia), solid soluble content (SSC) (AOAC 932.14) (digital refractometer, Atago Company Ltd, Tokyo, Japan) and total acidity (TA) (titration with $0.1 \mathrm{~N}$ sodium hydroxide solution, Auros química, Bogotá, Colombial were evaluated at $20^{\circ} \mathrm{C}$ as described by [7]. For liquid samples $(X 1, X 2, X 3$, $X 4, X 5, X 6), 10 \mathrm{~mL}$ was taken directly for $\mathrm{pH}$ determination and three drops for solid soluble content determination. For the solid samples (X7, X8 and X9) the same amount of sample was taken but from a dilution of the sample in distilled water 1:10. Previously, the calibration of the $\mathrm{pH}$ meter was carried out with reference solutions of $\mathrm{pH} 4.00,7.00$ and 10.00 (Thermo scientific, Bogotá, Colombia). The moisture content was determined at 105 ${ }^{\circ} \mathrm{C}$ with a moisture scale (AOAC 925.10) (Mettler Toledo HB43-S Halogen Classic Plus, Ohio, USA). All analysis was performed in the Research Center for Engineering Processes in the Jorge Tadeo Lozano University, Bogotá.

\section{Color evaluation}

Color at three equidistant points was determined using a chromameter (CR-300, Minolta, Ramsey, NY, USA). Lightness $\left(L^{*}\right)$ was determined in a range from 0 (black) to 100 (white). The color component $a^{*}$ varies from green (negative values) to red (positive), the color component $b^{*}$ varies from blue (negative values) to yellow (positive). $\mathrm{A} \mathrm{BaSO}_{4}$ plate was used as a reference standard $\left(L=96.9, a^{*}=0, b^{*}=7.2\right)$.

$$
\begin{aligned}
& \text { The results are expressed as color index } \\
& \left(\mathrm{Cl}=\left[\left(a^{*}\right)(1000)\right] /\left[\left(L^{*}\right)\left(b^{*}\right)\right]\right), \\
& \left(C^{*}=\sqrt{a^{* 2}+b^{* 2}}\right) \quad \text { and color } \begin{array}{r}
\text { difference } \\
\left(\triangle E=\left[(\triangle L)^{2}+\left(\triangle a^{*}\right)^{2}+\left(\triangle b^{*}\right)^{2}\right]^{1} / 2\right)
\end{array} \\
& (\triangle E
\end{aligned}
$$

\section{Minerals}

$0.3 \mathrm{~g}$ of each sample was digested in $9 \mathrm{~mL}$ of nitric acid: perchloric (5:2) in a microwave digester (Milestone, Ethos Plus, Shelton, US). The digestion program consisted of a ramp time of $5 \mathrm{~min}$ to reach $180^{\circ} \mathrm{C}$ and digestion for 10 min [8]. Phosphorous (P), potassium (K), calcium (Ca), magnesium (Mg), sodium ( $\mathrm{Na}$ ), sulfur (S), iron (Fe), copper ( $\mathrm{Cu}$ ), manganese (Mn), zinc ( $\mathrm{Zn})$, arsenic (As) and lead $(\mathrm{Pb})$ were determined using an atomic absorption spectrum (Agilent Technologies 280FS AA, Bayan Lepas, Malaysia). Nitrogen (N) was determined through the EPA method (Environmental Protection Agency) [9] and Boron (B) through the NTC (Colombian Technical Standard) [10].

\section{Reducing sugars}

The reducing sugars were determined through the reducing sugars method of Lane and Eynon [11]. The samples were subjected to strong acid hydrolysis to unfold the starches and to obtain glucose.

\section{Heat capacity}

The heat capacity was determined at $25{ }^{\circ} \mathrm{C}$ with a bomb calorimeter (IKA $®$ Calorimeter System C 2000 basic C 2000 control, Works, Inc. North Chase, Wilmington) according to $[12,13]$. The measurement was performed to $1 \mathrm{gram}$ of the sample.

\subsection{Statistical analysis}

The differences between the technologies throughout the production process were evaluated using an analysis of variance (ANOVA, $\mathrm{P} \leq 0.05$; Statgraphics Centurion 18, software shop, Bogotá, Colombial. The differences were identified using a multiple range least significant difference (LSD) test of mean values. 


\section{Results and discussion}

\subsection{Effect of the technologies on the change of the $\mathrm{pH}$, acidity and ash during the process of NCS elaboration}

The $\mathrm{pH}$ of cane juice ranged from 5.18 (T2) to 5.24 (T1), data similar to those reported in Hoya del Río Suárez (HRS), departments of Santander and Boyacá-Colombia (5.36) and Candelaria municipality, Valle del Cauca- Colombia (5.21). The average $\mathrm{pH}$ of the zones where sugarcane is cultivated varies between 5.0 and 5.2 [14]. In X4, a pH increase of $18.96 \%$ (T1) and $2.66 \%$ (T2) was observed, reaching $5.96 \mathrm{pH}$ (T1) and $5.02 \mathrm{pH}$ (T2). This was due to the fact that food grade lime was added in the process to minimize the inversion of the sucrose molecule. The $\mathrm{pH}$ should be increased to 5.6-6.0 (molded NCS) and up to 6.4 (granulated NCS) [14]; therefore the $\mathrm{pH}$ (T2) was not within these parameters, this may be due to the fact that the initial $\mathrm{pH}$ of the juice in $\mathrm{T} 2$ was significantly lower than in $T 1$ ( $p \leq 0.05$ ), in addition this is a manual process in which the operator always adds the same amount of lime, without taking into account the measurement of this parameter. Food grade lime acts as a clarification aid, allowing the efficiency in the clarification process to be increased by the destabilization that the $\mathrm{pH}$ change produces on the color precursor material, allowing an easy removal and rinsing of the product, besides it creates a protective barrier of the sucrose molecule, impeding its hydrolysis and loss of quality [14]. Significant differences ( $p \leq 0.05$ ) in the interaction between technologies and stages were observed throughout the NCS elaboration process (Figure 1).

Total acidity (TA) in cane juice ranged from 1.39 (T2) to 1.45 (T1) g citric acid $\mathrm{L}^{-1}$ (Figure 2) and no significant differences were found between T1 and T2 ( $\leq \leq 0.05)$. However, in $\mathrm{X} 3$ there were differences due to the equipment used (pre-cleaner 2) in each NCS processing plant, as well as the amount of impurities of the cane used. In this stage, it is allowed a greater elimination of solids which can affect the content of TA. The raw juice contains impurities such as soil, bagasse and its residues, therefore it is necessary to subject it to pre-cleaning systems, which retain by physical means the greatest amount of impurities [14]. However, both the pre-cleaner design and the operation, since it is manual, can affect the removal of impurities. In $X 4$ with respect to $X 3$, a decrease of $72.82 \%$ (T1) and $64.28 \%$ (T2) occurred possibly due to the addition of a mucilage called balso (Heliocarpus americanus $L$ ), which is bark of a tree previously macerated and filtered and acts efficiently agglutinating the particles and allowing their removal. Its binding action results from the clarifying action with juices and heat, forming dark, dense and consistent flocs called "cachaza", which are removed before the boiling process [14]

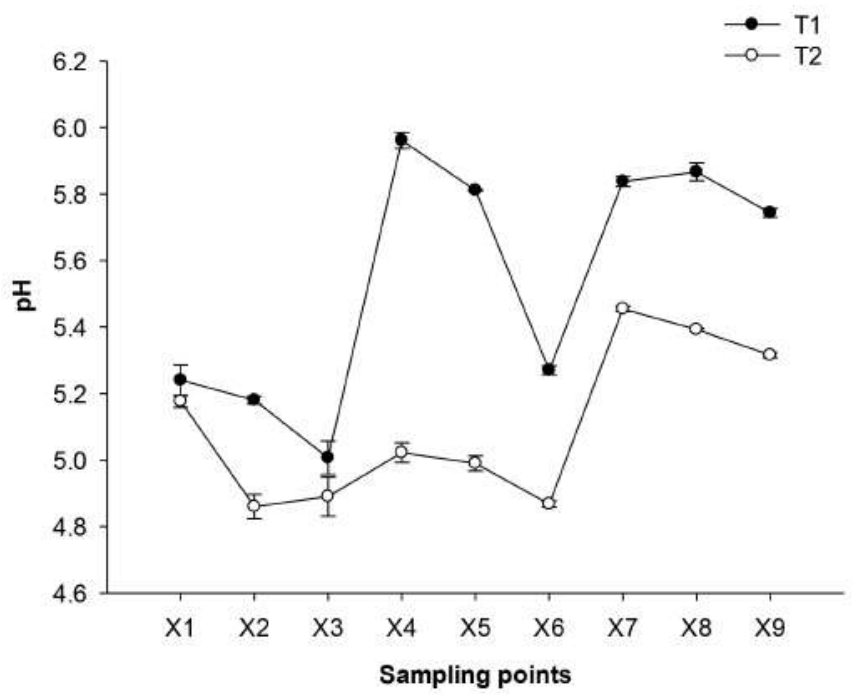

Figure 1 Effect of the technologies on the change of the $\mathrm{pH}$ of NCS elaboration. Mean ( $n=3) \pm$ SE. Analysis of variance ( $p \leq$

0.05) showed as significant factors the sampling points and processing technologies. $\mathrm{LSD}_{\text {sampling points }}=0.034$ $\mathrm{LSD}_{\text {sampling points-processing technologies }}=0.048$

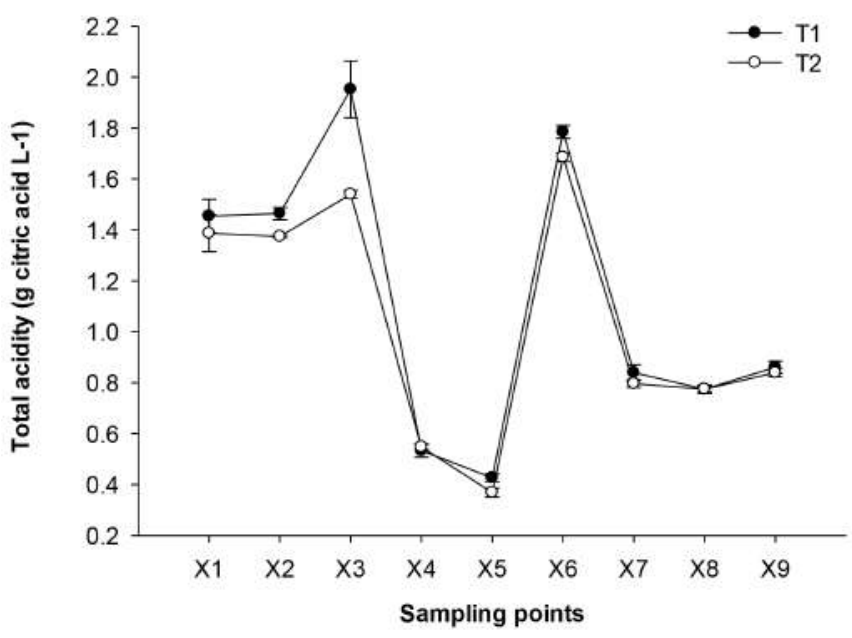

Figure 2 Effect of the technologies on the change of the acidity (g citric acid $L^{-1}$ ) of NCS elaboration. Mean $(n=3) \pm S E$. Analysis of variance ( $p \leq 0.05$ ) showed as significant factors the sampling

points and processing technologies. $\mathrm{LSD}_{\text {sampling points }}=0.087$, $\mathrm{LSD}_{\text {sampling points-processing technologies }}=0.123$

The values of ash depend on the composition of the cane and the juice, they presented a similar behavior during the process (Figure 3). A decrease was observed in the early stages $X 1, X 2$, and $X 3$, due to the large amount of solids (cane particles, bagasse, impurities) that are removed. From $\mathrm{X}$, an increase in the ash content was observed because the concentration of the cane juice begins. In $X 9$, the NCS was obtained with $26 \mathrm{~g} \mathrm{~kg}^{-1}$ of ash, a value that is 
between the range reported (3-36 $\left.\mathrm{g} \mathrm{kg}^{-1}\right)$ [5], (11.5-26.3 $\mathrm{g}$ $\mathrm{kg}^{-1}$ ) [15] and the existing regulations (minimum $8 \mathrm{~g} \mathrm{~kg}^{-1}$ for NCS blocks and minimum $10 \mathrm{~g} \mathrm{~kg}^{-1}$ for NCS granulated) [1]. In X4 and X5 not all the salts were removed from the juice, but they remained in it until obtaining the NCS, which could affect its quality. Ash in sugarcane juice is an important aspect that refers to the soluble inorganic salts contained in sugarcane juice. [16] mentioned that a high ash/reducing sugar ratio would increase the likelihood of loss of sucrose for molasses and would effectively affect the yield and quality of the raw sugar.

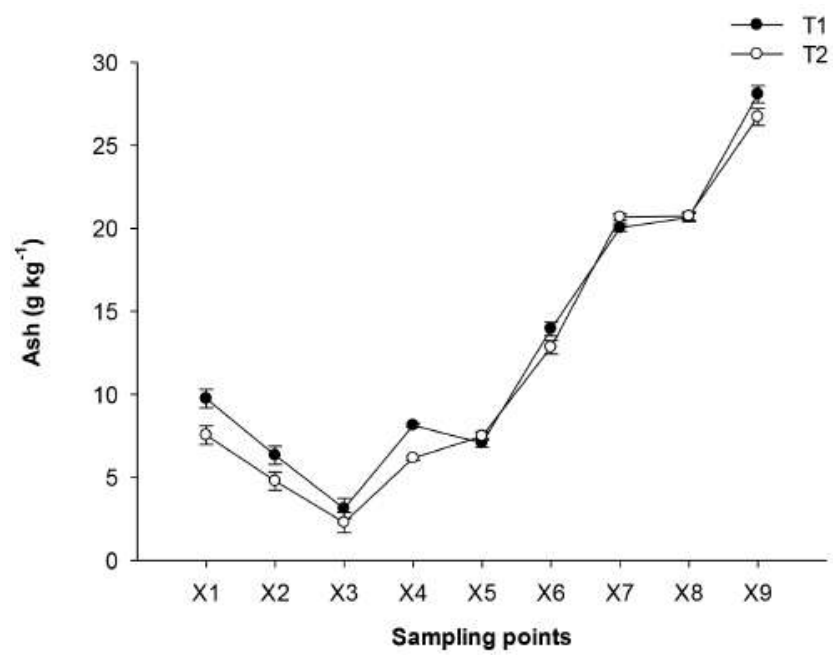

Figure 3 Effect of the technologies on the change of the ash $\mathrm{lg}$ $\mathrm{kg}^{-1}$ ) of NCS elaboration. Mean $(\mathrm{n}=3) \pm \mathrm{SE}$. Analysis of variance ( $p \leq 0.05$ ) showed as significant factors the sampling points and processing technologies. $\mathrm{LSD}_{\text {sampling points }}=0.676$, $\mathrm{LSD}_{\text {sampling points-processing technologies }}=0.957$

\subsection{Effect of technologies on solid soluble content (SSC)}

The SSC ranged from 17.51 to $18.86^{\circ} \mathrm{Brix}$ and no significant differences were found between T1 and T2 (Figure 4), these values were lower than those reported [17] with 19.99 ${ }^{\circ}$ Brix, HRS-Colombia (21.65 ${ }^{\circ}$ Brix), Candelaria- Colombia (20.4 ${ }^{\circ} \mathrm{Brix}$ ) and Cuba (19.29 $\left.{ }^{\circ} \mathrm{Brix}\right)$. However, the results can fluctuate between $16-24^{\circ} \mathrm{Brix}$ but ideally they should be as high as possible. The SSC variability depends on the agronomic conditions and climatic conditions, such as age, rain cycles, light hours and maturity of the cane [14]. In the first stages ( $X 1$ to $X 4$ ), the SSC remained constant since these are stages of cleaning and clarification, then from $X 5$ to $X 9$ a progressive increase was observed. In $X 6$, a significant difference ( $p \leq 0.05$ ) was observed between the two technologies with respect to $X 5$, where T2 concentrated the sample more ( 3.24 vs 3.03 times) than $T 1$, because the improved furnace design with ward combustion chamber and modified pan (T2) can increase efficiency by the temperature reached in the chamber $\left(1200{ }^{\circ} \mathrm{C}\right)$ as opposed to $\mathrm{T} 1\left(900^{\circ} \mathrm{C}\right)$. At $\mathrm{X} 7$ and $\mathrm{X} 8$, there were no significant differences ( $p \leq 0.05$ ) between the technologies concentrating the SSC 1.2 times and 1.01 times, respectively. Finally, SSC at X9 ranged from 89.88 ${ }^{\circ}$ Brix (T1) to $90.32{ }^{\circ}$ Brix (T2) and no significant differences $(p \leq 0.05)$ were found between T1 and T2 ( $p \leq 0.05)$. Similar values to those reported (90-96 ${ }^{\circ}$ Brix) [14] but lower than those reported [17] for the same variety RD 75-11 with 98.1 ${ }^{\circ}$ Brix. Through evaporation, it was possible to pass on average $18.19^{\circ} \mathrm{Brix}$ in clarified juices to $67.08^{\circ} \mathrm{Brix}$ syrups and to NCS of $90.1^{\circ} \mathrm{Brix}$, with a concentration of juice to NCS of 5.19 times (T1) and 4.86 times (T2).

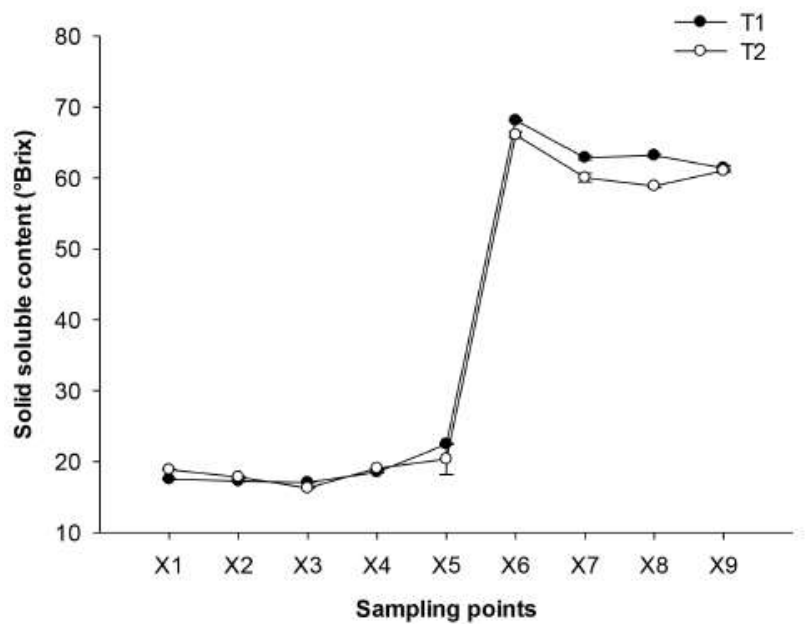

Figure 4 Effect of the technologies on the change of the solid soluble content ( ${ }^{\circ}$ Brix) of NCS elaboration. Mean ( $\left.n=3\right) \pm$ SE. Analysis of variance ( $p \leq 0.05$ ) showed as significant factors the sampling points and processing technologies. $\mathrm{LSD}_{\text {sampling points }}=$ $0.528, L_{S D}$ sampling points-processing technologies $=1.585$

\subsection{Effect of technologies on color}

In $X 1$, significant differences ( $p \leq 0.05$ ) were observed in cane juice with Chroma values of 6.25 (T1) and 12.34 (T2), indicating that the color of T2 was more saturated than T1, both in cane juice and in the product (X9), also $\triangle E^{*}$ indicated that the color difference is greater in $\mathrm{X} 9$, with significant differences ( $p \leq 0.05)$ between T1 and T2, starting from the same cane variety (Table 1). NCS can have different colors depending on the raw material used, the variety of the cane, the agro-ecological conditions and the elaboration process [1].

In the last stages $(X 6, X 7, X 8, X 9)$ a significant decrease ( $p \leq 0.05$ ) in the $L^{*}$ values was observed, whereas the values of $a^{*}, b^{*}, C^{*}, \mathrm{IC}, \triangle E^{*}$ increased, a similar behavior to that reported [18]. The values of $L^{*}$ decreased by the evaporation of the juice, solids concentration and caramelization of the sugars, the values of $a^{*}$ turned to 
Table 1 Effect of technologies on color

\begin{tabular}{|c|c|c|c|c|c|c|c|}
\hline Technology & Points & $\mathrm{L}^{*}$ & $a^{*}$ & $\mathbf{b}^{*}$ & Chroma & $\mathrm{Cl}$ & $\triangle \boldsymbol{E}$ \\
\hline \multirow{9}{*}{ T1 } & $\mathrm{X1}$ & $97.1 \pm 0.1$ & $2.0 \pm 0.1$ & $-5.9 \pm 0.2$ & $6.3 \pm 0.3$ & $-3.5 \pm 0.0$ & $8.0 \pm 0.3$ \\
\hline & $x 2$ & $97.1 \pm 0.1$ & $2.0 \pm 0.1$ & $-5.9 \pm 0.2$ & $6.2 \pm 0.3$ & $-3.6 \pm 0.0$ & $7.9 \pm 0.3$ \\
\hline & X3 & $97.0 \pm 0.0$ & $1.9 \pm 0.0$ & $-5.6 \pm 0.0$ & $5.9 \pm 0.0$ & $-3.6 \pm 0.0$ & $7.6 \pm 0.0$ \\
\hline & $X 4$ & $97.4 \pm 0.0$ & $2.2 \pm 0.0$ & $-6.4 \pm 0.0$ & $6.7 \pm 0.0$ & $-3.5 \pm 0.0$ & $8.4 \pm 0.0$ \\
\hline & $x 5$ & $96.8 \pm 0.0$ & $2.0 \pm 0.0$ & $-5.8 \pm 0.0$ & $6.1 \pm 0.0$ & $-3.5 \pm 0.0$ & $7.8 \pm 0.0$ \\
\hline & $x 6$ & $97.0 \pm 0.1$ & $2.2 \pm 0.1$ & $-6.2 \pm 0.2$ & $6.6 \pm 0.2$ & $-3.6 \pm 0.0$ & $8.3 \pm 0.2$ \\
\hline & $\mathrm{X} 7$ & $54.0 \pm 1.1$ & $9.1 \pm 0.2$ & $35.4 \pm 1.0$ & $36.5 \pm 0.5$ & $4.8 \pm 0.2$ & $55.4 \pm 0.1$ \\
\hline & $x 8$ & $50.7 \pm 0.8$ & $10.0 \pm 0$ & $31.5 \pm 1.1$ & $33.0 \pm 1.3$ & $6.3 \pm 0.3$ & $56.0 \pm 1.1$ \\
\hline & X9 & $31.6 \pm 0.4$ & $9.3 \pm 0.4$ & $11.2 \pm 0.3$ & $14.6 \pm 0.4$ & $26.6 \pm 0.6$ & $66.8 \pm 0.1$ \\
\hline \multirow{9}{*}{ T2 } & $\mathrm{X} 1$ & $99.2 \pm 0.0$ & $4.9 \pm 0.0$ & $-11.3 \pm 0.0$ & $12.3 \pm 0.0$ & $-4.3 \pm 0.0$ & $14.2 \pm 0.0$ \\
\hline & $x 2$ & $99.2 \pm 0.0$ & $4.9 \pm 0.0$ & $-11.3 \pm 0.0$ & $12.3 \pm 0.0$ & $-4.3 \pm 0.0$ & $14.0 \pm 0.0$ \\
\hline & X3 & $99.3 \pm 0.0$ & $4.9 \pm 0.0$ & $-11.2 \pm 0.0$ & $12.2 \pm 0.0$ & $-4.4 \pm 0.0$ & $14.0 \pm 0.0$ \\
\hline & $X 4$ & $99.2 \pm 0.0$ & $4.8 \pm 0.0$ & $-11.3 \pm 0.0$ & $12.3 \pm 0.0$ & $-4.3 \pm 0.0$ & $14.0 \pm 0.0$ \\
\hline & X5 & $99.2 \pm 0.1$ & $4.8 \pm 0.0$ & $-11.4 \pm 0.0$ & $12.4 \pm 0.0$ & $-4.3 \pm 0.0$ & $14.2 \pm 0.0$ \\
\hline & $x 6$ & $99.2 \pm 0.0$ & $3.7 \pm 0.0$ & $-11.1 \pm 0.0$ & $11.7 \pm 0.0$ & $-3.3 \pm 0.0$ & $14.4 \pm 0.0$ \\
\hline & $\mathrm{X7}$ & $45.8 \pm 2.4$ & $8.9 \pm 0.3$ & $26.7 \pm 2.8$ & $28.2 \pm 3.1$ & $7.6 \pm 1.0$ & $58.0 \pm 1.0$ \\
\hline & $x 8$ & $46.4 \pm 1.2$ & $7.8 \pm 0.1$ & $26.0 \pm 1.2$ & $27.1 \pm 1.4$ & $6.6 \pm 0.5$ & $56.8 \pm 0.7$ \\
\hline & $x 9$ & $37.2 \pm 0.7$ & $10.0 \pm 0$ & $15.5 \pm 0.4$ & $18.5 \pm 0.1$ & $17.2 \pm 0.5$ & $62.2 \pm 0.5$ \\
\hline
\end{tabular}

red and the values of $b^{*}$ to yellow. The $\mathrm{Cl}$ changed from a yellow color in $\mathrm{X} 1(-3.54 \mathrm{~T} 1,-4.33 \mathrm{~T} 2, \mathrm{Cl}<0=$ yellow $)$, then an intense yellow color in $\mathrm{X} 8(6.28 \mathrm{~T} 1,6.57 \mathrm{~T} 2, \mathrm{Cl}<5$ $=$ intense yellow), to a color in the final product (X9) from deep orange to deep red $(26.56 \mathrm{~T} 1, \mathrm{Cl}+20$ to +40$)$ and from pale yellow to intense orange $(17.24 \mathrm{~T} 2, \mathrm{Cl}+2$ to +20$)$. This change of color is due to the fact that in $\mathrm{X} 6$ about $90 \%$ of the water evaporates and it is transformed into a sweet, dense and viscous liquid of variable color. X7 is a critical stage of the process at high temperatures $\left(100-125^{\circ} \mathrm{C}\right)$ in which antifoaming agents are added to prevent syrup from adhering to the walls, caramelizing and burning [14], which would directly affect the color. Finally, in X8 and X9 the color and consistency is determined directly by SSC and temperature; If it is removed at a high temperature, it will present a caramelization of the sugars with its consequent darkening, otherwise its solidification will be difficult. NCS without chemical additives presents a progressive darkening by the action of the light [14]. According to the norm, it is the use of dyes, sodium hydrosulphite or sodium hyposulphite, or other chemical substances with whitening properties is not allowed [1].

\subsection{Composition of minerals in syrup and NCS}

The major minerals in $\mathrm{X} 6$ and $\mathrm{X} 9$ were $\mathrm{K}, \mathrm{Ca}, \mathrm{N}, \mathrm{Mn}, \mathrm{Fe}, \mathrm{B}$, $\mathrm{Cu}$ and $\mathrm{Zn}$ (Table 2). Both $\mathrm{K}$ and $\mathrm{Ca}$ decreased in $\mathrm{X} 9$ when using $\mathrm{T} 2$, by $47.7 \%$ and $22.73 \%$ respectively, this can be attributed to the temperature of the combustion chamber in $\mathrm{T} 2$.
The contents of $\mathrm{Mn}, \mathrm{Fe}, \mathrm{Cu}$ and $\mathrm{Zn}$ increase from $\mathrm{X} 6$ to $\mathrm{X} 9$, due to the concentration of the samples. The values of $\mathrm{K}$ in NCS ( $4.7 \mathrm{~g} \mathrm{~kg}^{-1} \mathrm{~T} 1,2.40 \mathrm{~g} \mathrm{~kg}^{-1}$ T2), Ca (2.8 g kg-1 $\left.T 1,1.7 \mathrm{~g} \mathrm{~kg}^{-1} \mathrm{~T} 2\right)$ and $P\left(0.2 \mathrm{~g} \mathrm{~kg}^{-1} \mathrm{~T} 1 ; 0.4 \mathrm{~g} \mathrm{~kg}^{-1} \mathrm{~T} 2\right)$ were higher than that required in the standard $\left(1 \mathrm{~g} \mathrm{~K} \mathrm{~kg}^{-1} ; 0.1\right.$ $\left.\mathrm{g} \mathrm{Ca} \mathrm{kg}^{-1} ; 0.05 \mathrm{~g} \mathrm{P} \mathrm{kg}^{-1}\right) 1$. However, the Fe values in NCS ( $0.009 \mathrm{~g} \mathrm{~kg}^{-1} \mathrm{~T} 1,0.012 \mathrm{~g} \mathrm{~kg}^{-1} \mathrm{~T} 2$ ) are below those required in the standard $\left(0.015 \mathrm{~g} \mathrm{~kg}^{-1}\right)$ [1]. Sugarcane contains major elements ( $\mathrm{N}, \mathrm{P}, \mathrm{K}$ ), intermediate nutrients ( $\mathrm{Ca}, \mathrm{Mg}$ ) and secondary nutrients (S, Fe); $\mathrm{Fe}$ is necessary in the synthesis of chlorophyll and is an essential component for the enzymatic activity [14]; however, according to the results obtained, it is possible that the agronomic conditions and the variety did not allow a higher Fe content in the final product. Other authors also reported higher $\mathrm{K}$ and $\mathrm{Ca}$ content in NCS $\left(5.31 \mathrm{~g} \mathrm{~K} \mathrm{~kg}^{-1}, 5.0 \mathrm{~g} \mathrm{~K} \mathrm{~kg}^{-1}\right.$ and $1.02 \mathrm{~g} \mathrm{Ca} \mathrm{kg}^{-1}, 2.5 \mathrm{~g} \mathrm{Ca} \mathrm{kg}^{-1}$ ] [5, 19]. NCS is a natural sweetener and provides a higher mineral content than syrup (0.96 $\mathrm{g} \mathrm{K} \mathrm{kg}^{-1}$ and $0.26 \mathrm{~g} \mathrm{Ca} \mathrm{kg}^{-1}$ ) [19] and refined sugar powder which does not have a mineral content [20]. $K$ is found in fruits and fresh vegetables, whole grains, meats, salmon, milk, yogurt and pumpkin, is necessary for proper balance of fluids, the nervous and muscular system, proper maintenance of blood pressure and waste disposal [21].

The $\mathrm{K}$ values obtained in NCS $14.70 \mathrm{~g} \mathrm{~kg}^{-1} \mathrm{~T} 1 ; 2.40 \mathrm{~g}$ $\mathrm{kg}^{-1} \mathrm{~T}$ ) ) are similar to those found in bananas $(3.58 \mathrm{~g}$ $\mathrm{kg}^{-1}$ ), broccoli $\left(3.16 \mathrm{~g} \mathrm{~kg}^{-1}\right)$, and higher than those found in products such as grape $\left(2.03 \mathrm{~g} \mathrm{~kg}^{-1}\right)$, grapefruit $(1.48$ $\left.\mathrm{g} \mathrm{kg}^{-1}\right)$ and watermelon $\left(1.12 \mathrm{~g} \mathrm{~kg}^{-1}\right)$ [20]. Ca is found in broccoli, mustard leaves, milk, fortified tofu, fortified soy 
Table 2 Composition of minerals in syrup and NCS

\begin{tabular}{|c|c|c|c|c|}
\hline \multirow{2}{*}{ Minerals } & \multicolumn{2}{|c|}{ Technology 1} & \multicolumn{2}{|l|}{ Technology 2} \\
\hline & $\mathrm{X6}$ & $\mathrm{X9}$ & $\mathrm{X6}$ & $\mathrm{X9}$ \\
\hline Nitrogen, $\mathrm{N}\left(\mathrm{g} \mathrm{kg}^{-1}\right)$ & $1.1 \pm 0.0 \mathrm{a}$ & $0.9 \pm 0.0 \mathrm{ab}$ & $1.1 \pm 0.0 \mathrm{a}$ & $0.8 \pm 0.0 \mathrm{~b}$ \\
\hline Phosphorus, $\mathrm{P}\left(\mathrm{g} \mathrm{kg}^{-1}\right)$ & $0.1 \pm 0.0 b$ & $0.2 \pm 0.0 \mathrm{ab}$ & $0.1 \pm 0.0 b$ & $0.4 \pm 0.0 \mathrm{a}$ \\
\hline Potassium, $\mathrm{K}\left(\mathrm{g} \mathrm{kg}^{-1}\right)$ & $4.6 \pm 0.0 a$ & $4.7 \pm 0.0 \mathrm{a}$ & $4.5 \pm 0.0 \mathrm{a}$ & $2.4 \pm 0.0 \mathrm{~b}$ \\
\hline Calcium, Ca $\left(\mathrm{g} \mathrm{kg}^{-1}\right)$ & $2.2 \pm 0.0 \mathrm{~b}$ & $2.8 \pm 00 \mathrm{a}$ & $2.2 \pm 0.0 \mathrm{~b}$ & $1.7 \pm 0.0 c$ \\
\hline Magnesium, $\mathrm{Mg}\left(\mathrm{g} \mathrm{kg}^{-1}\right)$ & $0.5 \pm 0.0 \mathrm{~ns}$ & $0.6 \pm 0.0 \mathrm{~ns}$ & $0.5 \pm 0.0 \mathrm{~ns}$ & $0.5 \pm 0.0 \mathrm{~ns}$ \\
\hline Sodium, Na $\left(\mathrm{g} \mathrm{kg}^{-1}\right)$ & $0.1 \pm 1.0 b$ & $0.2 \pm 1.8 a$ & $0.1 \pm 2.0 \mathrm{~b}$ & $0.1 \pm 3.7 b$ \\
\hline Sulfur, $S\left(\mathrm{~g} \mathrm{~kg}^{-1}\right)$ & $0.3 \pm 0.0 b$ & $0.4 \pm 0.0 \mathrm{a}$ & $0.3 \pm 0.0 b$ & $0.4 \pm 0.0 \mathrm{a}$ \\
\hline Iron, Fe (mg kg-1) & $4.86 \pm 0.3 c$ & $9.74 \pm 0.4 b$ & $4.87 \pm 0.3 c$ & $11.86 \pm 0.6 a$ \\
\hline Copper, Cu (mg kg$\left.{ }^{-1}\right)$ & $2.72 \pm 0.2 \mathrm{~ns}$ & $2.99 \pm 0.3 \mathrm{~ns}$ & $2.72 \pm 0.2 \mathrm{~ns}$ & $3.08 \pm 0.2 \mathrm{~ns}$ \\
\hline Manganese, $\mathrm{Mn}\left(\mathrm{mg} \mathrm{kg}^{-1}\right)$ & $2.72 \pm 0.7 c$ & $11.74 \pm 0.6 \mathrm{a}$ & $6.19 \pm 0.2 b$ & $12.10 \pm 1.7 \mathrm{a}$ \\
\hline Zinc, Zn $\left(\mathrm{mg} \mathrm{kg}^{-1}\right)$ & $2.01 \pm 0.1 b$ & $2.27 \pm 0.1 b$ & $2.01 \pm 0.1 b$ & $3.18 \pm 0.3 a$ \\
\hline Boron, B (mg kg ${ }^{-1}$ ) & $5.00 \pm 0.0 \mathrm{~ns}$ & $<5.00 \mathrm{~ns}$ & $5.00 \pm 0.0 \mathrm{~ns}$ & $<5.00 \mathrm{~ns}$ \\
\hline Arsenic, As (mg kg$\left.{ }^{-1}\right)$ & $1.21 \pm 0.6 a$ & $0.01 \pm 0.0 b$ & $0.03 \pm 0.0 b$ & $0.01 \pm 0.0 \mathrm{~b}$ \\
\hline Lead, $\mathrm{Pb}\left(\mathrm{mg} \mathrm{kg}^{-1}\right)$ & $0.42 \pm 0.0 b$ & $0.82 \pm 0.0 a$ & $0.43 \pm 0.0 b$ & $0.75 \pm 0.0 a$ \\
\hline
\end{tabular}

milk, salmon and sardines. It is important for healthy bones and teeth, muscle relaxation, the nervous system, the immune system, the circulatory system and the regulation of blood pressure [21].

The Ca values obtained in NCS $\left(2.80 \mathrm{~g} \mathrm{~kg}^{-1} \mathrm{~T} 1 ; 1.70 \mathrm{~g}\right.$ $\mathrm{kg}^{-1} \mathrm{~T}$ 2) are higher than those found in broccoli $(1.20 \mathrm{~g}$ $\left.\mathrm{kg}^{-1}\right)$, mustard leaves $\left(1.15 \mathrm{~g} \mathrm{~kg}^{-1}\right)$, milk soybeans with added calcium $\left(1.24 \mathrm{~g} \mathrm{~kg}^{-1}\right)$ and lower than those reported for tofu $\left(3.72 \mathrm{~g} \mathrm{~kg}^{-1}\right) .{ }^{21} \mathrm{Mn}$ is a micromineral available in hazelnuts, squash, beans, spinach, brown rice, mussels, fish, whole wheat and tofu. It is important for the normal functioning of the brain and the nervous system; it is also useful for women during the postmenopause and for the prevention of osteoporosis [21]. The Mn values obtained in NCS $\left(0.012 \mathrm{~g} \mathrm{~kg}^{-1}\right)$ are similar to those found in pistachio $\left(0.01 \mathrm{~g} \mathrm{~kg}^{-1}\right)$ [20]. These results suggest that NCS is a potential source of important minerals in the prevention of various diseases.

\subsection{Reducing sugars}

Reducing sugars X1 (16.9 $\left.\mathrm{g} \mathrm{kg}^{-1}\right)$ did not present significant differences ( $\leq \leq 0.05)$ in T1 and T2 (data not shown). These values are within the range $\left(10-18 \mathrm{~g} \mathrm{~kg}^{-1}\right)$ reported [17] considered normal for the NCS crystallization process. In $X 9$, the reducing sugars presented a significant difference ( $p \leq 0.05)$ being higher in T2 $\left(70.8 \mathrm{~g} \mathrm{~kg}^{-1}\right)$ than in T1 $(66.6$ $\mathrm{g} \mathrm{kg}^{-1}$ ). However, in both cases the normative is met (minimum $55 \mathrm{~g} \mathrm{~kg}^{-1}$ ] [1]. According to the results obtained, it is possible that at T2 (> temperature combustion) a higher acid hydrolysis of the polysaccharides occurs during cooking, which releases other simpler sugars [22]. In time, syrup with a content greater than $70^{\circ}$ Brix tend to be separated into two phases: one semi-solid (sucrose) and another one super-rich in reducing sugars Iglucose and fructose). Glucose is one of the monosaccharides present in cane juice, is the most stable form, it crystallizes as a monohydrate, and forms rhomboid crystals having a melting point of $146{ }^{\circ} \mathrm{C}$ (anhydrous) and $83^{\circ} \mathrm{C}$ (hydrated). Fructose is more soluble in water than glucose and melts at $102-104^{\circ} \mathrm{C}[14]$.

\subsection{Heat capacity}

The energy values obtained (Table 3 ) are similar to those reported for NCS $\left(15700 \mathrm{~J} \mathrm{~g}^{-1}, 15533 \mathrm{~J} \mathrm{~g}^{-1}\right)[20,23]$ higher than those reported for sugar beet $\left(12727 \mathrm{~J} \mathrm{~g}^{-1}\right)$ [20], syrup (13062 J g-1) [23], and lower than those reported for refined sugar (16747 J g-1) [20]. Current consumer trends are framed towards the consumption of products free of preservatives, colorants and additives; beverage companies grow exponentially and, being aware of these changes, they increasingly cover a wide range of products with new features, flavors and forms. For this reason, NCS could be included in drinks as a natural sweetener and a source of minerals in the diet.

\subsection{Moisture content}

There were significant differences $(p \leq 0.05)$ in T1 technology $\left(52.2 \pm 2.14 \mathrm{~g} \mathrm{~kg}^{-1} \quad X 7 ; 56 \pm 1.5 \mathrm{~g} \mathrm{~kg}^{-1} \quad\right.$ X8; $\left.59.5 \pm 1.17 \mathrm{~g} \mathrm{~kg}^{-1} \times 9\right)$ with respect to T2 $\left(72.7 \pm 0.7 \mathrm{~g} \mathrm{~kg}^{-1} \times 7\right.$; $73.5 \pm 1.2 \mathrm{~g} \mathrm{~kg}^{-1} \times 8 ; 75.6 \pm 1.1 \mathrm{~g} \mathrm{~kg}^{-1} \times 9$ ) (data not shown). However, with both technologies the moisture content of NCS was as required in the standard (Maximum $90 \mathrm{~g} \mathrm{~kg}^{-1}$ ) 
Table 3 Heat capacity in NCS

\begin{tabular}{|c|c|c|c|c|}
\hline \multirow{2}{*}{ Technology } & \multicolumn{2}{|l|}{$\mathrm{X6}$} & \multicolumn{2}{|l|}{$\mathrm{X9}$} \\
\hline & $\begin{array}{l}\text { Heat capacity } \\
\left(\mathrm{J} \mathrm{g}^{-1}\right)\end{array}$ & Kcal g-1 & $\begin{array}{l}\text { Heat capacity } \\
\left(\mathrm{J} \mathrm{g}^{-1}\right)\end{array}$ & Kcal g-1 \\
\hline T1 & $15216.6 \pm 24.8 \mathrm{Aa}$ & $3.64 \pm 0.01 \mathrm{Aa}$ & $14753.9 \pm 50.4 \mathrm{Bb}$ & $3.53 \pm 0.01 \mathrm{Bb}$ \\
\hline $\mathrm{T} 2$ & $15221.2 \pm 22.05 \mathrm{Aa}$ & $3.64 \pm 0.01 \mathrm{Aa}$ & $14615.9 \pm 21.7 \mathrm{Cb}$ & $3.49 \pm 0.01 \mathrm{Cb}$ \\
\hline
\end{tabular}
sifferent letters indicate significant differences $(p<0.05$ ) according to LSD's multip
showed significant differences in the parameters of heat capacity (LSD $=0.044$ ).

[1]. The moisture content is of great importance to avoid the deterioration of the NCS due to the development of microorganisms on the surface, like molds and yeasts (Maximum 150 UFC $\mathrm{g}^{-1}$ )[1].

\section{Conclusions}

The NCS making process started with cane juice with average values of $5.21 \mathrm{pH}, 1.42 \mathrm{~g}$ citric acid $\mathrm{L}^{-1}, 8.6 \mathrm{~g}$ $\mathrm{L}^{-1}$ ash, $18.19{ }^{\circ}$ Brix and $16.9 \mathrm{~g} \mathrm{~L}^{-1}$ of reducing sugars, obtaining NCS with average values of $5.53 \mathrm{pH}, 0.85 \mathrm{~g}$ citric acid $\mathrm{L}^{-1}, 26 \mathrm{~g} \mathrm{~L}^{-1}$ ash, $90.1^{\circ}$ Brix and $68.7 \mathrm{~g} \mathrm{~L}^{-1}$ reducing sugars.

The cane juice presented significant differences ( $p \leq$ 0.05 ) in color (Chroma of $6.25 \mathrm{~T} 1$ and $12.34 \mathrm{~T} 2$ ) even within the same variety (RD 75-11). During the process, a change in color was observed in the cane juice $(\mathrm{Cl}<0=$ yellow), in the evaporation $(\mathrm{Cl}<5=$ intense yellow) and finally in the $\mathrm{NCS}(\mathrm{Cl}+20$ to $+40=$ intense orange to deep red, $\mathrm{Cl}+2$ to $+20=$ pale yellow to intense orange).

The technology with improved furnace with Ward combustion chamber and modified pan (T2) managed to concentrate the CSS of syrup (X6) to NCS (X9) in a 36.03 $(\%)$ unlike T1 (32.59\%). Additionally, a higher texture in the finished product and a higher concentration of reducing sugars (70.8 $\mathrm{g} \mathrm{L}^{-1}$ ) was obtained as opposed to T1 166.6 $\mathrm{g} \mathrm{L}^{-1} \mathrm{~J}$. However, with this technology $\mathrm{K}$ was reduced by $47.77 \%$ and $\mathrm{Ca}$ by $22.73 \%$.

NCS has a high calorific value (14684.9 $\mathrm{Jg}^{-1}$ ) and could be used as a natural sweetener in energy drinks. In addition, it is a source of minerals and has properties which are beneficial to health.

\section{Acknowledgements}

The authors are grateful to the owners of the NCS processing plant of the Municipality San José de Pare for allowing sample gathering. Thanks to the Colombian Corporation for Agricultural Research (AGROSAVIA, and Jorge Tadeo Lozano University for the development of this study.

\section{References}

[1] Colombian technical standard 1311, ICONTEC, 2009.

[2] W. Jaffé, "Health effects of non-centrifugal sugar (ncs): A review," Sugar Tech, vol. 14, no. 2, pp. 87-94, Jun. 2012.

[3] (2016) Food and Agriculture Organization of the United Nations,FAOSTAT. FAO. Accessed Nov. 01, 2018. [Online]. Available: http://www.fao.org/faostat/es/\#home

[4] G. Rodriguez, H. Garcia, Z. Roa, and P. Santacoloma, "Panela production as a strategy for diversifying incomes in rural area of Latin America," FOOD AND AGRICULTURE ORGANIZATION OF THE UNITED NATIONS, Rome, IT, Tech. Rep., 2007.

[5] W. Jaffé, "Nutritional and functional components of non centrifugal cane sugar: A compilation of the data from the analytical literature," Journal of Food Composition and Analysis, vol. 43, November 2015. [Online]. Available: https://doi.org/10.1016/j.jfca.2015.06.007

[6] H. García, L. Albarracin, A. Toscano, N. Santana, and 0. Intuasty. (2007) Guía tecnológica para el manejo integral del sistema productivo de caña panelera. Corporación Colombiana de Investigación Agropecuaria. Colombia. [Online]. Available: https://bit.ly/2OcYZH9

[7] M. Tarazona, J. Viegas, M. Moldao, and E. Aguayo, "Bioactive compounds from flesh and by-product of spanish freshcut watermelon cultivars," Journal of the Science of Food Agriculture, vol. 91, no. 5, March 30 2011. [Online]. Available: http: //doi.org/10.1002/jsfa.4250

[8] M. Tarazona and E. Aguayo, "Assessment of by-products from fresh-cut products for reuse as bioactive compounds," Food Science and Technology International, vol. 19, no. 5, July 15 1996. [Online]. Available: http://doi.org/10.1177/1082013212455346

[9] "Nitrogen, Kjeldahl, Total (Colorimetric; Titrimetric; Potentiometric)," EPA, Environmental Protection Agency, Tech. Rep. Method 351.3, 1978.

[10] Norma técnica colombiana 5404: Calidad del suelo, Determinación de Boro, ICONTEC, 2011.

[11] "Official Method 923.09 in Lane and Eynon general volumetric method," AOAC, Association of Official Analytical Chemists, International, Tech. Rep. 923.09.

[12] Testing of solid and liquid fuels - Determination of gross calorific value by the bomb calorimeter and calculation of net calorific value, DIN 51900-1:2000-04, 2000.

[13] Solid mineral fuels, Determination of gross calorific calue by the bomb calorimetric method, and calculation of net calorific value, International Organization for Standardization 1928:1995, 1995.

[14] N. Durán, Reingeniería panelera, 1st ed. Colombia: Buhos Editores, 2010.

[15] M. Guerra and M. Mujica, "Physical and chemical properties of granulated cane sugar "panelas"," Food Science and Technology, vol. 30, no. 1, January/March 2010. [Online]. Available: http: //dx.doi.org/10.1590/S0101-20612010005000012

[16] P. Jackson and et al, "Management of ash/impurity ratio in sugarcane: relative effects of genotypes, and $\mathrm{N}$ and $\mathrm{K}$ fertiliser 
rates," Australian journal of agricultural research, vol. 59, no. 9, pp. 795-801, 2013.

[17] J. Ramírez, O. Insuasty, and C. Viveros, "Comportamiento agroindustrial de diez variedades de caña de azúcar para producción de panela en Santander, Colombia. Corpoica," Ciencia y Tecnología Agropecuaria, vol. 15, no. 2, pp. 183-195, 2014.

[18] P. Rao and M. Das and S. Das, "Changes in physical and thermo-physical properties of sugarcane, palmyra-palm and date-palm juices at different concentration of sugar," Journal of Food Engineering, vol. 90, no. 4, February 2009. [Online]. Available: https://doi.org/10.1016/j.jfoodeng.2008.07.024

[19] S. Kadri, R. Zaluski, and R. Orsi, "Nutritional and mineral contents of honey extracted by centrifugation and pressed processes," Food Chemistry, vol. 218, September 12 2016. [Online]. Available: https://doi.org/10.1016/j.foodchem.2016.09.071
[20] Branded Food Products Database. United States Department of Agriculture. Accessed jun. 17, 2017. [Online]. Available: https: //ndb.nal.usda.gov/ndb/search/list

[21] S. Taghi and S. Jafari, "The importance of minerals in human nutrition: Bioavailability, food fortification, processing effects and nanoencapsulation," Trends in Food Science and Technology, vol. 62, April 2017. [Online]. Available: https://doi.org/10.1016/j.tifs.2017. 02.017

[22] R. Núñez, B. Rivas, R. Hernández, and M. Chirinos, “Contenido de azúcares totales, reductores y no reductores en Agave cocui Trelease," Multiciencias, vol. 12, no. 2, pp. 129-135, 2012.

[23] Instituto Colombiano de Bienestar Familiar-ICBF. (2015) Tabla de composición de alimentos colombianos (TCAC). Digiprint editores SAS. [Online]. Available: https://bit.ly/2Fbloys 